\title{
'n Teoretiese basis vir kontekstualisering in tweetalige woordeboeke*
}

\author{
Herman L. Beyer, Departement Taal- en Literatuurstudie, Universiteit van \\ Namibië, Windhoek, Namibië en Departement Afrikaans en Nederlands, \\ Universiteit Stellenbosch, Stellenbosch, Republiek van Suid-Afrika \\ (hbeyer@unam.na)
}

Opsomming: Die hoofdoel van 'n tweetalige woordeboek kan beskou word as die kommunikatiewe bemagtiging van die woordeboekgebruiker deur die voorsiening van semanties-pragmatiese vertaalekwivalente ter wille van kommunikatiewe ekwivalensie. Wanneer 'n vertaalekwivalentparadigma aangebied word, moet die woordeboekgebruiker deur funksionele ekwivalentdiskriminerende inskrywings gehelp word om die kommunikatief gepaste vertaalekwivalent te selekteer vir die doel van teksresepsie, teksproduksie of vertaling binne die tersaaklike diskoerssituasie, d.w.s. die data-aanbod in die woordeboek behoort die gebruiker in die toepassing van ekwivalentdiskriminasie te ondersteun. In hierdie artikel word ' $n$ teoretiese fundering van sodanige aanbod voorgestel, wat gebaseer word op die relevante literatuur en woordeboekdata. Die potensiaal van ' $n$ kommunikatiewe benadering tot 'n gebruikersgerigte metaleksikografie word in die proses verken. Daar word vasgestel dat ekwivalentdiskriminerende inskrywings in 'n algemene tweetalige woordeboek binne die paradigma van konteks, soos leksikografies toegepas, aangebied word, en bepaalde klasse kontekstualiserende inskrywings word geïdentifiseer. Die verspreidingstruktuur van dié inskrywingstipes kom ook kortliks aan bod. 'n Kommunikatiewe benadering benadruk dat die kommunikatiewe sukses van 'n woordeboek deur 'n goed beplande woordeboekspesifieke leksikografiese proses én woordeboekgebruik deur bevoegde teikengebruikers medebepaal word.

Sleutelwoorde: BETEKENISVERKLARING, BUITETEKS, DEKODERING, DISKRIMINATOR, EKWIVALENTDISKRIMINASIE, EKWIVALENTDISKRIMINERENDE INSKRYWING, ENKODERING, GEBRUIKERSGERIGTE METALEKSIKOGRAFIE, INGEVOEGDE TEKS, KOLLOKASIE, KOMMUNIKATIEWE BENADERING, KOMMUNIKATIEWE EKWIVALENSIE, KONTEKS, KONTEKSLEIDING, KONTEKSTUALISERENDE INSKRYWINGS, KONTEKSTUALISERING, KOTEKS, LEKSIKOGRAFIE, LEKSIKOGRAFIESE DATA, LEKSIKOGRAFIESE ETIKET, LEKSIKOGRAFIESE GLOS, SEMANTIES-PRAGMATIESE EKWIVALENSIE, TWEETALIGE WOORDEBOEK, VERSPREIDINGSTRUKTUUR, VRY KONSTRUKSIE

* Hierdie artikel is 'n aangepaste weergawe van 'n gedeelte van 'n hoofstuk uit 'n D.Litt.proefskrif, ' $n$ Metaleksikografiese ondersoek na konteksleiding in Afrikaanse vertalende woordeboeke, wat in April 2006 deur die Universiteit Stellenbosch, Stellenbosch, Republiek van SuidAfrika, aanvaar is.

Lexikos 19 (AFRILEX-reeks/series 19: 2009) 1-22 
Abstract: A Theoretical Foundation for Contextualisation in Bilingual Dictionaries. The main aim of a bilingual dictionary may be regarded as the communicative empowerment of the dictionary user through the presentation of semantic-pragmatic translation equivalents for the purpose of communicative equivalence. When a translation equivalent paradigm is offered, the dictionary user should be assisted in selecting the communicatively appropriate translation equivalent for the purpose of text reception, text production or translation in a specific discourse situation by functional equivalent discriminating entries, i.e. the data presentation in the dictionary should support the user in the application of equivalent discrimination. This article proposes a theoretical foundation for such a presentation, which is based on the relevant literature and dictionary data. The potential of a communicative approach to a user-directed metalexicography is explored in the process. It is established that equivalent discriminating entries in a general bilingual dictionary are presented within the paradigm of context, as lexicographically applied, and specific classes of contextualising entries are identified. The distribution structure of these entries is briefly touched on. A communicative approach emphasises that the communicative success of a dictionary is co-determined by both a well-planned dictionary specific lexicographic process and dictionary use by competent target-users.

Keywords: BILINGUAL DICTIONARY, COLLOCATION, COMMUNICATIVE APPROACH, COMMUNICATIVE EQUIVALENCE, CONTEXT, CONTEXTUAL GUIDANCE, CONTEXTUALISATION, CONTEXTUALISING ENTRY, CO-TEXT, DECODING, DEFINITION, DISCRIMINATOR, DISTRIBUTION STRUCTURE, ENCODING, EQUIVALENT DISCRIMINATION, EQUIVALENT-DISCRIMINATING ENTRY, FREE CONSTRUCTION, INSERTED TEXT, LEXICOGRAPHIC DATA, LEXICOGRAPHIC GLOSS, LEXICOGRAPHIC LABEL, LEXICOGRAPHY, OUTER TEXT, SEMANTIC-PRAGMATIC EQUIVALENCE, USER-DIRECTED METALEXICOGRAPHY

\section{Inleiding}

Zgusta (1971: 294) vat die algemene doel van tweetalige woordeboeke soos volg saam:

The basic purpose of a bilingual dictionary is to coordinate with the lexical units of one language those lexical units of another language which are equivalent in their lexical meaning.

Leksikale items in die brontaal word met leksikale items in die doeltaal gekoördineer wat dieselfde betekenis verteenwoordig, oftewel wat semanties ekwivalent is. Sodanige doeltaalitems word vertaalekwivalente genoem. Volgens Wiegand (2002: 248) gaan dit egter nie uitsluitlik om die aanduiding van semantiese ekwivalensie nie: Die tweetalige woordeboek behoort na semantiespragmatiese ekwivalensie te streef. Dit veronderstel dat die vertalende leksikograaf nie alleen die verantwoordelikheid het om een of 'n aantal semantiespragmatiese vertaalekwivalente vir elke brontaallemma aan te bied nie, maar ook om die woordeboekgebruiker deur funksionele addisionele woordeboekinskrywings benewens die vertaalekwivalente te lei om vir die tersaaklike dis- 
koerssituasie die gepaste vertaalekwivalent te selekteer én om die geselekteerde vertaalekwivalent dan gepas en korrek in die geval van teksresepsie, teksproduksie of vertaling toe te pas, dit wil sê ter wille van kommunikatiewe ekwivalensie (vgl. Gouws 1996: 16). Hierdie eis geld veral indien as gevolg van die anamorfisme tussen tale daar slegs gedeeltelike ekwivalensie tussen bronen doeltaalitem bestaan (vgl. Gouws en Prinsloo 2005: 154). Die doel van sodanige funksionele addisionele woordeboekinskrywings behoort dus te wees om die woordeboekgebruiker te help om ter wille van kommunikatiewe ekwivalensie tussen die aangebode vertaalekwivalente te diskrimineer, dit wil sê om ekwivalentdiskriminasie toe te pas.

\section{Ekwivalentdiskriminasie}

Daardie addisionele funksionele woordeboekinskrywings wat die funksie moet vervul om die woordeboekgebruiker te help met ekwivalentdiskriminasie word ekwivalentdiskriminerende inskrywings genoem. Die nut, en inderdaad essensiële behoefte aan ekwivalentdiskriminerende inskrywings in tweetalige woordeboeke word duidelik uit die volgende opmerkings deur Al-Kasimi (1977: 63):

(1)(a) Nida expressed the fluid and inconsistent nature of meaning of words in his three fundamental semantic presuppositions:

(i) No word (or semantic unit) ever has exactly the same meaning in two different utterances.

(ii) There are no complete synonyms within a language.

(iii) There are no exact correspondences between related words in different languages.

(b) Absolute equivalents which have exactly the same semantic and grammatical function in both languages [which are paired off in a bilingual dictionary] are rare.

Hieruit vloei die volgende resolusie (Al-Kasimi 1977: 68):

(2) The bilingual dictionary should provide meaning discriminations which enable the user to select the appropriate equivalent or the proper sense of an equivalent. And unless the problem of meaning discrimination is solved systematically, the bilingual dictionary cannot be a dependable guide to the proper equivalents.

Die gevolg is dat dit as een van die vertalende leksikograaf se primêre doelwitte beskou word om in sy/haar woordeboek 'n aanbod te bewerkstellig wat die ondubbelsinnige interpretasie van die aangebode data deur die teikengebruiker sal bewerkstellig (vgl. Gouws 2000: 40). Roberts (1990: 219) verwoord hierdie vereiste soos volg:

(3) $[\mathrm{I}] \mathrm{t}$ is no longer deemed sufficient to provide only translation equivalents for some language headwords, accompanied by an occasional example; it is now 
considered highly desirable to provide semantic and stylistic discrimination of equivalents, detailed grammatical information, and collocational specifications for each headword and even for each sense division of the headword.

Die vereiste is egter meer as "highly desirable" vir 'n tweetalige woordeboek wat ten doel het om kommunikatiewe ekwivalensie te bewerkstellig - dit is onontbeerlik. Kromann et al. (1991: 2724) beskou die afwesigheid van ekwivalentdiskriminerende inskrywings in tweetalige woordeboeke tereg as "one of the ancient and deadly sins of translation lexicography".

Volgens Wiegand (1989: 251) lei die produksie van woordeboeke tot die kulturele praktyk van woordeboekgebruik. In 'n gebruikersgerigte metaleksikografie (vgl. o.m. Gouws en Prinsloo 2005: 39-44) kan die verband tussen woordeboekproduksie en woordeboekgebruik sinvol vanuit 'n kommunikatiewe benadering aan die hand van 'n leksikografiese kommunikasiemodel beskryf word (vgl. Beyer 2006). Sodanige model benadruk onder meer dat die leksikograaf tydens die woordeboekspesifieke leksikografiese proses geselekteerde leksikografiese data in woordeboekinskrywings enkodeer en dat die woordeboekgebruiker tydens woordeboekgebruik die aangebode woordeboekinskrywings dekodeer om spesifieke inligting te onttrek ten einde kommunikatief bemagtig te word. ${ }^{1}$ Indien hierdie model op die tweetalige woordeboek toegepas word, is die implikasie dat kommunikatiewe ekwivalensie nie eensydig deur die leksikograaf bewerkstellig kan word nie, maar dat die woordeboekgebruiker ook 'n aktiewe rol in die proses speel. Met die fokus op die woordeboekspesifieke leksikografiese proses (d.i. die leksikograaf) kan gekonstateer word dat Afrikaanse tweetalige woordeboeke onvoldoende tot die medebewerkstelliging van kommunikatiewe ekwivalensie bydra, met ander woorde dat onvoldoende leksikografiese data geënkodeer word en/of dat leksikografiese data onvoldoende geënkodeer word: Volgens die literatuur blyk die probleem te wees dat onvoldoende ekwivalentdiskriminerende inskrywings aangebied word wat die kommunikasie-georiënteerde funksies van die woordeboek (vgl. Tarp 2000) ondersteun. Met die fokus op woordeboekgebruik kan gekonstateer word dat die woordeboekgebruiker onvoldoende leksikografiese data moet dekodeer en/of leksikografiese data onvoldoende dekodeer: Wanneer die woordeboekgebruiker met 'n vertaalekwivalentparadigma gekonfronteer word, moet hy/sy ekwivalentdiskriminasie toepas ten einde die naslaanprosedure te voltooi, ongeag die aanbod al dan nie van ekwivalentdiskriminerende inskrywings. Die vraag is of die gebruiker suksesvol sal wees én in hoe 'n mate die aanbod in die woordeboek tot hierdie uitkoms sal bydra. Hierdie vraag het ' $n$ tweesydige implikasie. In die eerste plek impliseer dit dat 'n onderskeid getref kan word tussen suksesvolle en onsuksesvolle ekwivalentdiskriminasie tydens woordeboekgebruik. Dié konsepte kan soos volg omskryf word:

(4) Suksesvolle ekwivalentdiskriminasie vind plaas wanneer die woordeboekgebruiker tydens woordeboekgebruik 'n kommunikatief gepaste vertaal- 
ekwivalent (d.i. 'n semanties-pragmatiese vertaalekwivalent) in 'n aangebode vertaalekwivalentparadigma vir die doel van teksresepsie, teksproduksie of vertaling in 'n spesifieke diskoerssituasie selekteer.

(5) Onsuksesvolle ekwivalentdiskriminasie vind plaas wanneer die woordeboekgebruiker tydens woordeboekgebruik 'n kommunikatief nié-gepaste vertaalekwivalent in 'n aangebode vertaalekwivalentparadigma vir die doel van teksresepsie, teksproduksie of vertaling in 'n spesifieke diskoerssituasie selekteer.

In die tweede plek kan 'n onderskeid getref word tussen (a) suksesvolle ekwivalentdiskriminasie wat gefasiliteer word deur die suksesvolle dekodering van funksionele leksikografiese data wat deur die leksikograaf in ekwivalentdiskriminerende inskrywings geënkodeer is, en (b) suksesvolle ekwivalentdiskriminasie wat plaasvind ten spyte van (die afwesigheid of gebrekkigheid van) die aanbod van ekwivalentdiskriminerende inskrywings. Geval (a) kan funksioneel-gefasiliteerde suksesvolle ekwivalentdiskriminasie genoem word, terwyl geval (b) insidenteel-suksesvolle ekwivalentdiskriminasie genoem kan word. Hierbenewens kan disfunksioneel-gefasiliteerde onsuksesvolle ekwivalentdiskriminasie onderskei word wanneer onsuksesvolle ekwivalentdiskriminasie gefasiliteer word as gevolg van (a) 'n gebrekkige aanbod van ekwivalentdiskriminerende inskrywings wat veroorsaak is deur die gebrekkige enkodering van funksionele leksikografiese data en/of die enkodering van disfunksionele leksikografiese data, en/of (b) die onsuksesvolle dekodering van funksionele leksikografiese data wat funksioneel in ekwivalentdiskriminerende inskrywings geënkodeer is.

Uiteraard behoort disfunksioneel-gefasiliteerde onsuksesvolle ekwivalentdiskriminasie ten alle koste voorkom te word. Om die woordeboekgebruiker aan sy/haar eie taalintuïsie oor te laat om óf onsuksesvolle ekwivalentdiskriminasie óf insidenteel-suksesvolle ekwivalentdiskriminasie toe te pas is leksikografies onverdedigbaar. 'n Gebruikersgerigte leksikografie streef na die uitkoms van funksioneel-gefasiliteerde suksesvolle ekwivalentdiskriminasie ter wille van kommunikatiewe ekwivalensie.

Die vraag is binne watter paradigma ekwivalentdiskriminerende inskrywings in die woordeboek aangebied behoort te word. Uit Gouws (1989: 160161) se beskrywing van die status en funksie van die vertaalekwivalent in die tweetalige woordeboek kan dié vraag beantwoord word. Die beskrywing lui soos volg:

(6) Die status van 'n vertaalekwivalent is dat dit 'n leksikale item uit die doeltaal is wat in sekere vasgestelde kontekste gebruik kan word om die lemma mee te vertaal. Die semantiese funksie van 'n vertaalekwivalent is dus dat dit 'n aanduiding moet gee van die betekeniswaarde wat 'n gegewe lemma in 'n spesifieke konteks het, deur aan te toon hoe daardie spesifieke betekeniswaarde in die doeltaal geleksikaliseer word. 
Indien die leksikograaf duidelikheid kan kry oor die aard en rol van die "sekere vasgestelde kontekste" waarin spesifieke vertaalekwivalente gebruik kan word om lemmata mee te vertaal, kan hy/sy verteenwoordigende data enkodeer in ekwivalentdiskriminerende inskrywings, met ander woorde die ekwivalentdiskriminerende inskrywings kan binne die paradigma van konteks aangebied word.

\section{Konteks}

Uit die beskrywing in (6) kan twee kenmerke van 'n vertaalekwivalent geïdentifiseer word: ' $n$ Vertaalekwivalent gee naamlik (a) 'n aanduiding van die betekeniswaarde van die lemma waaraan dit geadresseer is (b) met betrekking tot 'n spesifieke diskoerssituasie.

\subsection{Kenmerke van vertaalekwivalente}

\subsubsection{Kenmerk (a): Die semantiese funksie oftewel die primêre konteks}

In terme van kenmerk (a) redeneer Gouws (1989: 161) dat vertaalekwivalente konteksafhanklike woordeboekinskrywings is aangesien hulle semantiese data weergee, dit wil sê 'n vertaalekwivalent geld as sodanig slegs binne die konteks waarin dit semanties ekwivalent aan die doeltaallemma is. Buite dié konteks kan ' $n$ vertaalekwivalent nie bestaan nie. Semantiese ekwivalensie kan dus as die primêre konteks beskou word waarbinne vertaalekwivalente in die tweetalige woordeboek aangebied word. Dit is die tipe konteks wat geld in Zgusta (1971: 294) se formulering van die algemene doel van 'n tweetalige woordeboek soos aan die begin van hierdie artikel aangehaal, en dit verteenwoordig die semantiese aspek van Wiegand (2002: 248) se semanties-pragmatiese ekwivalensie.

\subsubsection{Kenmerk (b): Die diskoerssituasie oftewel die sekondêre konteks}

Kenmerk (b) verwys na die breër diskoerssituasie waarin kenmerk (a) geld, dus na die sekondêre konteks.

In Van Sterkenburg (2003: 393) word die term konteks vir leksikografiese doeleindes soos volg gedefinieer:

(7) the words, sentences or texts that come before and after a particular lexeme considered relevant to make its meaning clear.

Hoewel die definiens in (7) voldoende kan wees vir toepassing op verklarende woordeboeke, is dit te eng vir toepassing op tweetalige woordeboeke, aangesien dit by tweetalige woordeboeke in die eerste plek gaan oor die voorsiening van vertaalekwivalente, en nie die verklaring van betekenis nie. Crystal (1991: 
78-79) voorsien vier definiense van die term konteks, waarvan twee bruikbaar is vir die doel van hierdie bespreking:

(8)(a) A general term used in linguistics and phonetics to refer to specific parts of an utterance (or text) near or adjacent to a unit which is the focus of attention. The occurrence of a unit (e.g. a sound, word) is partly or wholly determined by its context, which is specified in terms of the unit's relations, i.e. the other features with which it combines as a sequence. The everyday sense of the term is related to this, as when one 'puts a word in context', in order to clarify the meaning intended, as in dictionary entries. Providing a context in this way is referred to as contextualisation. [...] Some scholars use the term co-text [...].

(b) A term referring to the features of the non-linguistic world in relation to which linguistic units are systematically used. The term situation is also used in this sense, as in the compound term situational context. In its broadest sense, situational context includes the total non-linguistic background to a text or utterance, including the immediate situation in which it is used, and the awareness by the speaker and hearer of what has been said earlier and of any relevant external beliefs or presuppositions. Further distinctions are usually made in semantics and stylistics, distinguishing, for example, referential and emotive meaning from contextual meaning, i.e. information is signalled about the kind of use a linguistic unit has in its social context, e.g. whether it has a 'restricted' use (as in social pleasantries, or religious settings), or how it relates to such factors as age, sex or class of the speakers.

Die definiens in (8)(a) kom ooreen met dié in (7), maar in (8) word die belangrike onderskeid tussen linguistiese konteks (ook koteks genoem) en buitetalige of pragmatiese konteks getref. Kharma (1984: 199) onderskei tussen die vergelykbare "context of situation" en "linguistic or verbal context". Jarošová (2000: 18) omskryf konteks as "the environment in which the lemma is correlated with the particular equivalent", wat vergelykbaar is met Gouws se formulering oor die aard van die vertaalekwivalent in (6). Beide vorme van sekondêre konteks, te wete koteks en pragmatiese konteks, speel 'n rol in ekwivalentdiskriminasie.

Die sekondêre konteks verteenwoordig die pragmatiese aspek van Wiegand (2002: 248) se semanties-pragmatiese ekwivalensie.

\subsection{Die terme konteks, kontekstualisering en konteksleiding leksikografies toegepas}

Die inligting in die voorgaande bespreking kan gekonsolideer word om die volgende werksdefinisie vir die term konteks, soos leksikografies toegepas, voor te stel:

(9) Met betrekking tot die tweetalige woordeboek verwys die term konteks na beide die primêre en sekondêre kontekste (soos bo verklaar) waarin 'n bepaalde vertaalekwivalent met ' $n$ brontaallemma gekoördineer word. 
Die konsep van konteks, leksikografies toegepas, kan skematies soos volg weergegee word:

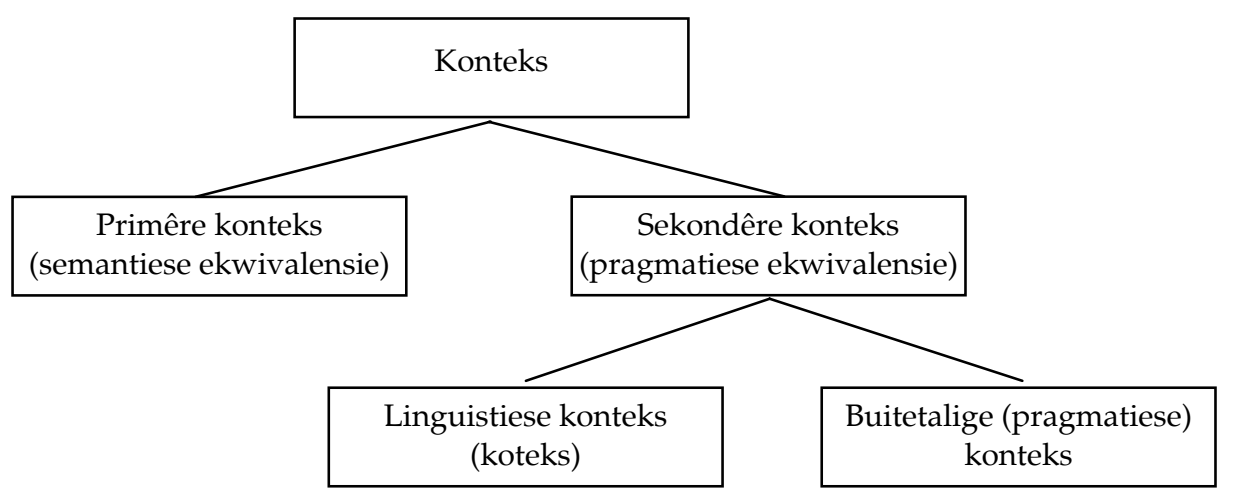

Leksikografiese data wat primêre of sekondêre konteks spesifiseer, kan kontekstuele leksikografiese data genoem word. Vervolgens kan 'n definisie vir kontekstualisering voorgestel word:

(10) Wanneer die leksikograaf kontekstuele leksikografiese data in ekwivalentdiskriminerende inskrywings enkodeer, vind kontekstualisering plaas. Kontekstualisering word in die woordeboek in kontekstualiserende inskrywings gemanifesteer.

Dit is moontlik om ekwivalentdiskriminerende inskrywings binne 'n ánder paradigma as dié van konteks aan te bied, met ander woorde ekwivalentdiskriminerende inskrywings is nie by verstek ook kontekstualiserende inskrywings nie: Kontekstualiserende inskrywings verteenwoordig 'n subklas ekwivalentdiskriminerende inskrywings. In die Superblokraaiselwoordeboek (Pansegrouw 1995) word die volgende artikel aangebied:

(11) ent afstand, end, entplek, gedeelte, immuniseer, inokulasie, (in)okuleer, smetstof, stuk, uiteinde, vaksinasiemerk, ver

Dié woordeboek kan as 'n intratalige vertalende woordeboek beskou word (vgl. Louw 1991: 117). Ten einde die teikengebruiker (die blokraaiselspeler) te help om (makliker) ekwivalentdiskriminasie toe te pas, sou die leksikograaf die artikel in (11) kon aanpas om soos volg daar uit te sien:

(12) ent afstand [7], end [3], entplek [7], gedeelte [8], immuniseer [10], inokulasie [10], (in)okuleer [(9) 7], smetstof [8], stuk [4], uiteinde [8], vaksinasiemerk [14], ver [3]

Die leksikograaf sou selfs kon afsien van die oorhoofse alfabetiese ordening van ekwivalente en die woordeboekartikel soos volg struktureer:

(13) ent 3: end, ver 4: stuk 7: afstand, entplek, okuleer 8: gedeelte, smetstof, uiteinde 9: inokuleer 10: immuniseer, inokulasie 14: vaksinasiemerk 
Die ekwivalentdiskriminerende inskrywings in (12) en (13) val buite die paradigma van konteks soos leksikografies toegepas (omdat sodanige paradigma nie die teikengebruiker in die betrokke gebruiksituasie van hulp sal wees in ekwivalentdiskriminasie nie), maar binne die paradigma van die aantal letters waaruit elke ekwivalent bestaan. Die blokraaiselwoordeboekopsteller wat die doel van sy woordeboek, sy teikengebruiker se behoeftes en die tipiese gebruiksituasie volledig in ag neem, sal weet dat die keuse van 'n ekwivalent by die invul van 'n blokraaisel primêr bepaal word deur die aantal letters waaruit die ekwivalent bestaan. Dit wil nié sê dat die ekwivalente in (11), (12) en (13) onafhanklik van konteks, soos leksikografies toegepas, aangebied word nie - die ekwivalente word soos in 'n intertalige vertalende woordeboek binne hulle primêre kontekste met die lemma gekoördineer en in 'n enkele woordeboekartikel saamgegroepeer (maar nié daarvolgens georden nie), want hulle verteenwoordig almal gedeeltelike sinonieme van die (verskillende homonimiese) leksikale items wat deur die lemmata verteenwoordig word (d.w.s. semantiese ekwivalensie geld wel). Die paradigma waarbinne die ekwivalentdiskriminerende inskrywings funksioneer, is egter nie dié van konteks, soos leksikografies toegepas, nie.

Die paradigma waarbinne ekwivalentdiskriminerende inskrywings in ' $n$ woordeboek aangebied word, word dus nie arbitrêr nie, maar deur die ware doel en funksie(s) van die woordeboek bepaal. Gegee 'n tweetalige woordeboek se ware doel, sy funksies en die gevolglike strewe na kommunikatiewe ekwivalensie deur die aanbod van semanties-pragmatiese vertaalekwivalente, kan aangeneem word dat konteks die paradigma is waarbinne ekwivalentdiskriminerende inskrywings in sodanige woordeboek aangebied sal word.

Gouws (2000: 41) beskou kontekstualisering as 'n kritiese faktor wanneer die kommunikatiewe sukses van ' $n$ tweetalige woordeboek bepaal word. Binne die raamwerk van ' $n$ kommunikatiewe benadering tot 'n gebruikersgerigte leksikografie is dit belangrik om daarop te let dat kontekstualisering deur die leksikograaf nie outomaties tot funksioneel-gefasiliteerde suksesvolle ekwivalentdiskriminasie deur die woordeboekgebruiker lei nie: Kontekstualisering deur die leksikograaf kan ook tot disfunksioneel-gefasiliteerde onsuksesvolle ekwivalentdiskriminasie deur die woordeboekgebruiker lei indien (a) kontekstuele leksikografiese data disfunksioneel deur die leksikograaf in kontekstualiserende inskrywings geënkodeer is en/of (b) kontekstualiserende inskrywings disfunksioneel deur die woordeboekgebruiker gedekodeer word. Scenario (a) impliseer dat daar tydens die leksikografiese proses onderskei kan word tussen funksionele kontekstualisering en disfunksionele kontekstualisering:

(14) Funksionele kontekstualisering vind plaas wanneer die leksikograaf funksionele kontekstuele leksikografiese data funksioneel in kontekstualiserende inskrywings enkodeer.

(15) Disfunksionele kontekstualisering vind plaas wanneer die leksikograaf disfunksionele kontekstuele leksikografiese data in kontekstualiserende 
inskrywings enkodeer en/of funksionele kontekstuele leksikografiese data disfunksioneel in kontekstualiserende inskrywings enkodeer.

Verder kan dit gebeur dat die woordeboekgebruiker aangebode kontekstualiserende inskrywings nié tydens ekwivalentdiskriminasie benut nie as gevolg van gebrekkige naslaanvaardighede, gebrekkige kennis van woordeboekstrukture en -funksies, gebrekkige vertroue in die woordeboek, 'n goed ontwikkelde taalintuïsie, ensovoorts, wat sal lei tot óf insidenteel-suksesvolle ekwivalentdiskriminasie óf onsuksesvolle ekwivalentdiskriminasie, maar in elk geval nie tot fuksioneel-gefasiliteerde suksesvolle ekwivalentdiskriminasie nie. Vanuit die perspektief van die leksikografiese proses is funksionele kontekstualisering dié prosedure wat die kommunikatiewe sukses van die woordeboek medebepaal. Vanuit die perspektief van woordeboekgebruik is suksesvolle dekodering van kontekstualiserende inskrywings (d.w.s. funksioneel-gefasiliteerde suksesvolle ekwivalentdiskriminasie) dié prosedure wat die kommunikatiewe sukses van die woordeboek medebepaal. Dit beteken dat die kommunikatiewe sukses van 'n tweetalige woordeboek nie onafhanklik van woordeboekgebruik bepaal kan word nie (hoewel onafhanklik van woordeboekgebruik daaroor gehipotetiseer kan word). Daarbenewens moet die kommunikatiewe sukses van die woordeboek opnuut deur die uitkoms van elke individuele naslaanprosedure bepaal word. Indien konstant suksesvolle naslaanprosedures as die gevolg van funksioneel-gefasiliteerde suksesvolle ekwivalentdiskriminasie die kommunikatiewe sukses van ' $n$ tweetalige woordeboek sou bevestig, sou dit daarop dui dat in terme van kontekstualisering 'n goed ontwerpte woordeboekspesifieke leksikografiese proses suksesvol toegepas is om die gewenste kenmerke van voorspelbaarheid, berekenbaarheid, ontleedbaarheid en kontroleerbaarheid (vgl. Wiegand 1997) aan die woordeboek te verleen.

Wanneer kommunikatiewe ekwivalensie deur funksionele kontekstualisering bewerkstellig word, het konteksleiding plaasgevind:

(16) Konteksleiding vind plaas wanneer funksionele kontekstualisering deur die leksikograaf lei tot funksioneel-gefasiliteerde suksesvolle ekwivalentdiskriminasie deur die woordeboekgebruiker, dit wil sê die woordeboekgebruiker is funksioneel deur die aangebode kontekstualiserende inskrywings gelei tot suksesvolle ekwivalentdiskriminasie. Dus: konteksleiding $=$ funksionele kontekstualisering + funksioneel-gefasiliteerde ekwivalentdiskriminasie

Vir konteksleiding om plaas te vind, is beide die ontwikkeling van 'n gebruikersvriendelike leksikografie en die vestiging van 'n woordeboekkultuur noodsaaklik (vgl. o.m. Gouws 1999).

Die res van hierdie artikel fokus op enkele aspekte van funksionele kontekstualisering. 


\section{Funksionele kontekstualisering}

\subsection{Tipes kontekstualiserende inskrywings}

Iannucci (1967: 201-203) en Al-Kasimi (1977: 70-71) onderskei die volgende soorte betekenis- en ekwivalentdiskriminerende inskrywings wat in die tweetalige woordeboek kan voorkom:

(17)(a) Punktuasie bied 'n soort negatiewe diskriminasie, deurdat betekenisonderskeidinge binne die doeltaalekwivalentparadigma deur middel van kommapunttekens aangedui word, terwyl woordsinonieme binne ' $n$ doeltaalsinoniemparadigma deur kommatekens geskei word.

(b) Woordklasaanduidings differensieer vertaalekwivalente ten opsigte van die verskillende woordsoortelike funksies waarin hulle met die lemma gekoördineer word.

(c) Leksikografiese definisies (betekenisbeskrywings) word aangewend om polisemiese waardes van lemmata te differensieer, dit wil sê om primêre konteks aan te dui.

(d) Kontekswoorde of -frases lig die sekondêre konteks uit waarbinne vertaalekwivalente optree wat daardeur bepaal word.

(e) Leksikografiese etikette word gebruik om lemmata en/of bepaalde vertaalekwivalente en/of koteksinskrywings vir 'n bepaalde pragmatiese konteks te merk.

(f) Voorbeeldsinne of -frases dui koteks aan.

Volgens Wiegand (1990: 34) moet die kommapunte wat vertaalekwivalente vir verskillende betekenisonderskeidinge van die lemma onderskei en kommas wat woordsinonieme skei binne die teorie van leksikografiese tekste nie as leestekens beskou word nie, maar as homonieme van die betrokke leestekens, omdat die normale funksies van kommapunte en kommas nie geld nie. Hierdie siening maak die ongekwalifiseerde toepassing van die term punktuasie onbruikbaar. Die ";" wat vertaalekwivalente vir die verskillende polisemiese waardes van die lemmateken onderskei, word 'n polisemie-aanduider genoem (Wiegand 1996: 5), en dié "," wat vertaalekwivalente binne 'n doeltaalsinoniemparadigma onderskei, word 'n nie-tipografiese struktuurmerker, spesifiek 'n verdelingsmerker genoem, waarvan die doel is om die woordeboekartikel se struktuur te ekspliseer deur duidelik identifiseerbare soeksones af te baken (Wiegand 1990: 34). Die merkers ";" en "," in die doeltaalekwivalentparadigmas van Afrikaanse tweetalige woordeboeke word dus gediskwalifiseer as kontekstualiserende inskrywings, aangesien die inskrywings se ware funksies is om die artikelteks te struktureer, en nie om kommentaar op vertaalekwivalente as sodanig te lewer nie. Wiegand se siening word in hierdie studie ondersteun, 
wat impliseer dat "punktuasie" hoogstens insidenteel-suksesvolle ekwivalentdiskriminasie kan bewerkstellig.

In die Groot Woordeboek/Major Dictionary (Eksteen 1997 - voortaan GW), Tweetalige Woordeboek / Bilingual Dictionary (Bosman et al. 1984 - voortaan TW), Pharos Afrikaans-Engels/English-Afrikaans Woordeboek/Dictionary (Du Plessis 2005 - voortaan Pharos) en Reader's Digest Afrikaans-Engelse Woordeboek/English-Afrikaans Dictionary (Grobbelaar 1987 - voortaan RD) word woordklasaanduiding slegs aangebied indien 'n lemma multifunksioneel ten opsigte van woordklas is. Volgens Wiegand (1988: 567) vervul die aangawe van woordklas twee funksies: eerstens voorsien dit grammatiese data ten opsigte van die daaropvolgende ekwivalente, en tweedens beperk dit die bereik van voorafgaande inskrywings wat grammatikale data weergee oor die woordsoortlike funksie wat die nuwe woordklasaangawe voorafgaan. Die aanduiding van woordklas geld dus nie as 'n ekwivalentdiskriminerende datakategorie nie, hoewel dit as ekwivalentdiskriminerende inligtingskategorie tydens woordeboekgebruik kan funksioneer (vgl. Wiegand 1988: 548), soos in die volgende artikel in die GW:

\section{(18) subliminal, (n) onderbewussyn; (a) onderbewus}

Die woordklasaanduidende inskrywings "(n)" en "(a)" kan hier bloot insidenteel-suksesvolle ekwivalentdiskriminasie bewerkstellig; dit word duidelik as die volgende artikel uit die GW beskou word, waarin die woordklasaanduidende inskrywings geen ware ekwivalentdiskriminerende funksie kan vervul nie:

(19) flake3, (n) vlok; vonk; skilfer; flentertjie; snysel, stukkie; laag, blad; of ICE, ysskots; of SNOW, sneeuvlok; (v) in vlokke val; afskilfer; streep; in dun blaaie afbreek; skoonmaak; pluis; $\sim$ d FISH, vlokkies vis, gevlokte vis; OFF, afskilfer [...]

Inskrywings wat woordklas aandui, word op grond van funksie derhalwe gediskwalifiseer as ekwivalentdiskriminerende en gevolglik kontekstualiserende inskrywings.

Die diskwalifikasie van "punktuasie" en woordklasaanduiding as kontekstualiserende inskrywings laat betekenisverklarings, kontekswoorde of -frases, leksikografiese etikette en voorbeeldsinne of -frases as potensiële kontekstualiserende inskrywings.

Die aanwending van betekenisverklarings verteenwoordig die eksplisering van die primêre konteks waarbinne vertaalekwivalente met lemmata gekoördineer word, naamlik semantiese ekwivalensie (i.t.v. Wiegand 2002: 246). Betekenisverklarings behoort dus as kontekstualiserende inskrywings beskou te word.

Volgens Iannucci (1967: 202) het kontekswoorde en -frases die spesifieke doel om as betekenisdiskriminators op te tree. Iannucci (1985: 61) onderskei tussen betekenisdiskriminators en vertaalkomplemente, waar eersgenoemde die 
betekenis van die lemma waaraan dit geadresseer is deur 'n woord of frase weergee, en laasgenoemde bloot 'n bepaalde vertaalekwivalent grammaties voltooi. Vergelyk ter illustrasie die volgende uittreksel uit die GW:

$$
\text { depose', (onder eed) getuig, verklaar; afsit, ontslaan (uit 'n amp). }
$$

Die Concise English Oxford Dictionary (Pearsall 2001) ken die volgende betekenisonderskeidinge aan die lemma depose toe:

(21)(a) 1 remove from office suddenly and forcefully

(b) 2 Law testify or give (evidence) on oath, especially in writing

Die vertaalekwivalent getuig word ten opsigte van die tweede betekenisonderskeiding van die lemma depose $((21)(b))$ aangebied. Die tersaaklike betekenisonderskeiding van die leksikale item getuig word soos volg in die Verklarende Handwoordeboek van die Afrikaanse Taal (Odendal en Gouws 2005 — voortaan HAT) verklaar:

\section{Getuienis aflê in 'n ondersoek of verhoor}

Dit is duidelik dat terwyl die semantiese kenmerk [+ onder eed] 'n integrale deel van die betekenis van die Engelse leksikale item depose uitmaak, dit in terme van die GW oënskynlik slegs 'n opsionele element van die betekenis van die Afrikaanse leksikale item getuig verteenwoordig, en dat dié deel buite konteks geaktiveer moet word deur die byvoeging van die bepaling onder eed. $\mathrm{Na}$ regte behoort dié bepaling nie tussen hakies in (20) te verskyn nie, omdat die volledige vertaalekwivalent onder eed getuig behoort te wees (vgl. Pharos se akkurater hantering by die lemma depose). In Iannucci se terme sal die inskrywing "(onder eed)" as vertaalkomplement beskou word, en sal die woordeboekartikel in (20) geen inskrywings ter verklaring van betekenisonderskeidinge (d.w.s. betekenisdiskriminators) bevat nie. Hierdie soort aanbod is moontlik die produk van die woordgerigte neiging wat steeds in die Afrikaanse leksikografie gemanifesteer word.

Gouws (1989: 171) neem die term vertaalkomplement by Iannucci oor, maar gebruik dit "effens anders [...] as wat Iannucci voorstel deurdat dit eerder verwys na semantiese konteksleiding" (oftewel: kontekstualisering). Hiervolgens sal die inskrywing "(uit 'n amp)" teenoor die vertaalekwivalent ontslaan in (20) as vertaalkomplement beskou word, aangesien die inskrywing die gepaste betekenisonderskeiding van die vertaalekwivalent aan die gebruiker duidelik stel, soos wat blyk uit die betekenisverklaring van die lemma ontslaan in die HAT:

(23)(a) 1 Los-, vrylaat uit gevangenskap

(b) 2 Nie langer in diens hou nie; afdank, in die pad steek

(c) 3 Vrystel, onthef van

Die vertaalkomplement "(uit 'n amp)" in (20) identifiseer tereg die tweede bete- 
kenisonderskeiding $((23)(b))$ van die leksikale item ontslaan as dié waarde in welke konteks ontslaan as vertaalekwivalent vir die brontaalitem depose gebruik kan word. Die bepaling onder eed by die vertaalekwivalent getuig sal hiervolgens bloot as 'n opsionele element van die vertaalekwivalent beskou word (indien die leksikograaf die bewerking as sodanig kan verdedig), en nie as vertaalkomplement nie.

Zgusta (1971: 329, 331, 336-340) onderskei tussen glosse, etikette en voorbeelde as kontekstualiserende inskrywings, en verdeel glosse later in verklarende en beperkende glosse (Zgusta 1987: 6). Roberts (1990: 226) gebruik ook die term glos. Svensén (1993: 146-148) onderskei tussen gebruiksvoorbeelde, metalinguistiese inligting en ensiklopediese inligting as tipes kontekstualiserende inskrywings.

Terwyl teoretici soos Iannucci $(1967,1985)$, Al-Kasimi (1977) en Svensén (1993) hulle terme uit die perspektief van betekenisdiskriminasie voorstel met die doel om konteksleiding te bewerkstellig, wys Manley et al. (1988: 284) op die belangrike uitgangspunt dat een van die hooffunksies van die tweetalige woordeboek diskriminasie tussen ekwivalente is, en nié tussen betekenisse nie. Volgens hulle moet 'n tweetalige woordeboek ekwivalensiegestruktureerd wees, en nie betekenisgestruktureerd nie (Manley et al. 1988: 299). Dit hou in dat sowel die inskrywings in die artikels in 'n tweetalige woordeboek as die struktuur van daardie artikels in die eerste plek daarop gerig moet wees om aan die gebruiker bruikbare vertaalekwivalente te voorsien, en nie om betekenis te beskryf nie. In hierdie verband meld Gouws (1996: 27-28) dat die beginsel van betekenisdiskriminasie wat in verklarende woordeboeke toegepas word, in tweetalige woordeboeke vervang behoort te word deur die beginsel van ekwivalentdiskriminasie, hoewel hierdie benadering uiteraard nie die aanbod van semantiese inligting in tweetalige woordeboeke negeer nie.

Manley et al. (1988) lewer verder kommentaar op die oënskynlik onaanvaarbare mengelmoes van terme wat in die literatuur voorgestel word om tipes kontekstualiserende inskrywings te beskryf en probeer om dit op te ruim deur hulle eie terme voor te stel: die terme is naamlik glosse (wat Gouws se vertaalkomplemente, Iannucci en Al-Kasimi se kontekswoorde en -frases, Zgusta se beperkende glosse, Roberts se glosse en Svensén se gebruiksvoorbeelde en ensiklopediese inligting omvat) en etikette. Hierdie twee klasse inskrywings word diskriminators genoem (Manley et al. 1988: 290). Grammatiese inligting en voorbeelde word laastens onderskei. Manley et al. (1988) se terminologie maak nie vir betekenisverklarings voorsiening nie.

Vervolgens word bepaal watter tipes kontekstualiserende inskrywings in die GW, TW, Pharos en RD voorkom ten einde 'n klassifikasie vir Afrikaanse tweetalige woordeboeke daar te stel. Vergelyk die volgende verteenwoordigende uittreksels uit die GW in (24):

(24)(a) perceiv'ing, skerpsiende; skerp; waarnemend; skrander, skerpsinnig percen'tage, persentasie; persentsgewys(e); on a $\sim B A S I S$, persentsgewys(e); $B Y$ $\sim S$, persentsgewys(e); point, persentasiepunt; error, persentasiefout. 
Percentage point refers to a (decimal) part of a percentage, e.g. if inflation rises by one percentage point (say from 10 to $11 \%$ ), the actual percentage rise is $10 \%$, while the rise in percentage points is $1 \%$.

per'cept, die waarneembare; waargenomene; waarneming.

perceptibil'ity, waarneembaarheid, merkbaarheid, aanskoulikheid.

percep'tible, waarneembaar, merkbaar, duidelik, aanskoulik.

percep'tion, waarneming, persepsie, besef, gevoel; invordering; insig, begrip; inning, ontvangs, toe-eiening (jur.).

percep'tive, opmerksaam; waarnemings=, gewaarwordings $=$; faculty, waarnemingsvermoë.

percept'iveness, perceptiv'ity, waarnemingsvermoë, insig.

percept'ual, waarnemings $=$, perseptueel.

perch $^{1}$, (n) baars (vis).

perch $^{2}$, (n) (-es), (dwars)stokkie (in 'n voëlkou); slaapstok (hoender); sitplek; veilige plek; roede (51/2 jt.); langwa (voertuig); HOP the , bokveld toe gaan; KNOCK off one's , uitstof; kafloop; the bird TAKES its , die voël stryk neer (gaan sit); (v) op 'n stok sit (hoender); neerstryk (voël); hoog en droog sit; ed on a hill, op 'n koppie geleë; er, takslaper, voël wat op 'n tak slaap.

(b) habeas corp'us, habeas corpus (bevelskrif om 'n gevangene voor die hof te bring).

In die artikeldeeltrajek in (24)(a) is dit duidelik dat die vertaalekwivalente wat vir die lemma perceiving aangebied word, van geen kontekstualiserende inskrywings voorsien is nie. ${ }^{2}$ Die woordeboekartikel van die lemma percentage bevat twee voorbeeldfrases met vertaalekwivalente, naamlik "on $a \sim B A S I S$, persentsgewys(e)" en "BY $\sim$, persentsgewys(e)". Hierdie konstruksies verteenwoordig kollokasies en word aangebied met die doel om die gebruiker te help met die aanwending van die lemma of 'n vertaalekwivalent tydens teksproduksie. Tussen die lemmata percentage error en percept verskyn 'n ingevoegde binneteks (vgl. Louw en Gouws 1996: 96-99), wat verdere ensiklopediese en gebruiksdata oor die lemma percentage point verstrek. Die woordeboekartikels van die lemmata percept, perceptibility en perceptible bevat geen kontekstualiserende inskrywings nie. Die laaste vertaalekwivalent in die woordeboekartikel van die lemma perception word deur middel van ' $n$ leksikografiese etiket "jur." gekontekstualiseer, wat daarop wys dat die betrokke vertaalekwivalent (toe-eiening) binne die regskonteks as 'n vertaalekwivalent van dié lemma geld. Die vertaalekwivalent wat vir die lemma perch ${ }^{1}$ aangebied word, en 'n aantal van die vertaalekwivalente in die woordeboekartikel van die lemma perch $^{2}$ word deur middel van glosse gekontekstualiseer. Die vertaalekwivalent (dwars)stokkie word van die glos in 'n voëlkou voorsien om die pragmatiese konteks aan te dui waarbinne dié ekwivalent die geldende ekwivalent vir die lemma perch is, ensovoorts. Die artikel van perch ${ }^{2}$ bevat ook twee voorbeeldfrases met vertaalekwivalente, naamlik "the bird TAKES its , die voël stryk neer (gaan sit)" en " ed on a hill, op 'n koppie geleë". Eersgenoemde is 'n kollo- 
kasie, en laasgenoemde kan as 'n "vry" sintagma beskou word waardeur ' $n$ vertaalekwivalent (geleë) aangebied word. (Hier geld ooradressering tussen die koteksafdeling en die vertaalekwivalentparadigma; vgl. Gouws 2000). Die ander inskrywings wat die voorkoms van voorbeeldfrases vertoon, is vaste uitdrukkings; hulle geld dus nie as kontekstualiserende of enige tipe ekwivalentdiskriminerende inskrywings nie en behoort na regte lemmastatus te geniet (vgl. Gouws 1989: 97-108). In die artikel van die lemma habeas corpus in (24)(b) word, naas die vertaalekwivalent wat kongruent aan die lemma is, die betekenisverklaring bevelskrif om 'n gevangene voor die hof te bring voorsien om die betekenis van die lemma (en die vertaalekwivalent) aan die gebruiker duidelik te maak. Die betekenisverklaring in die doeltaal verskyn in die tipiese artikelposisie van glosse.

\section{WOORDE IN AKSIE \\ deist/theist \\ Beide die deist en die theist glo in God. Eersgenoemde glo egter nie dat God Hom aan die mens openbaar nie, en ook nie dat 'n persoonlike verhouding met God moontlik is nie, terwyl laasgenoemde dit meestal wel glo.}

deify v. vergoddelik (fâRcho'dâlâk) exalt to divine rank, personify as a god; vereer (fâReer') worship, idolise; aanbid (unbât') adore, idolise (e.g. a person).

\section{dejected a. neerslagtig}

(neeRsluch'tâch) depressed, despondent, downcast, disconsolate, in low spirits; bedruk (bâdRâk') depressed, heavy-hearted, down in the dumps; moedeloos (mōō'dâloows) crestfallen, despondent, disheartened; terneergedruk (tâRneeR'châdRâk) and (unus.) terneergeslae (tâRneeR'châsluâa) downhearted, depressed, downcast; mistroostig (mâstRoows'tâch) sick at heart, sad; verslae (fâRsluâ) downcast, downhearted, low-spirited; bek-af dehorn' horings verwyder of afsaag, onthoring. dehorn'ed cattle onthoringde beeste; poenskoppe, poenskop beeste. dehorn'er onthoorner. dehorn'ing onthoorning. dehorni'ing paste onthoorningsalf.

dehum'anise, =ize ontmens, verdierlik, tot ' $n$ dier maak. dehumanisa'tion, =zation ontmens(lik)ing, verdierliking.

dehumid'ify ontvog(tig). dehumidifica'tion ontvogt(ig)ing. dehumid'ifier ontvogt(ig)er.

dehusk' (uit)dop; (af)dop, pel; maize mielies afmaak. Vid. husk $v$.

dehy'drate ontwater, water onttrek, dehidr(a)teer, anhidreer. dehy'drant wateronttrekkende middel. dehydra'tion ontwatering, wateronttrekking, dehidrasie, dehidr(at)ering, dehidra(ta)sie. dehy'drator, dehydrat'or ontwateraar, ontwatertoestel

dehydro'genate, dehydro'genise, =ize dehidrogeneer. dehydrogen(is)a'tion, = (iz)a'tion dehidrogenering, dehidrogenasie.

de-ice' ontys. de-ic'er ontyser, ysbestryder.

de'icide godsmoord; godsmoordenaar.

deic'tic aanwysend, deikties.

de'ify vergood; vergoddelik; vereer, aanbid. deifica'tion vergoding; vergoddeliking. de'ifier vergoder. de'iform goddelik van gedaante.

deign (sig) verwerdig, toelaat.

Deir'dre Deirdre.

de'ist $n$. deïs. de'ist $a$., deis'tic(al) deïsties. de'ism deïsme. de'ity godheid; goddelikheid.

deject' neerslagtig maak, ontmoedig. deject'a (mv.) uitwerpsels (med.). deject'ed neerslagtig, bedruk, moedeloos, terneergedruk, terneergeslae, mistroostig, verslae, bek-af, triestig, troosteloos, hangkop. deject'edly kop-onderstebo. dejec'tion neerslagtigheid, bedruktheid, terneergedruktheid, mistroostigheid, moedeloosheid, verslaen(t)heid; (terneer)geslaenheid; ont- 


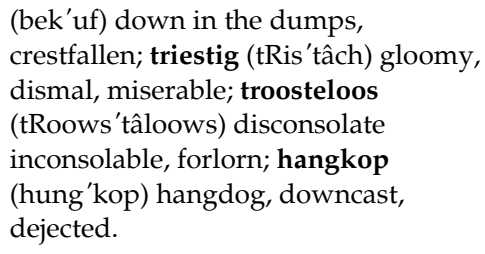

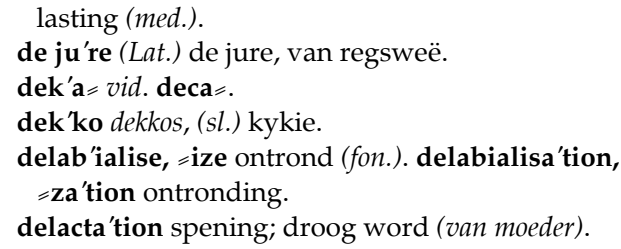

In (25) verteenwoordig die regterkantste kolom die primêre makrostruktuur in die RD wat die woordeboekartikels bevat. Leksikografiese etikette kom voor in die artikels van die lemmata dejecta, dejection, de jure, dekko en delabialise: die vertaalekwivalente uitwerpsels en ontlasting word gemerk as ekwivalente binne die pragmatiese konteks van mediese vaktaal; by die lemma de jure word aangedui dat dié lemma uit Latyn afkomstig is; die vertaalekwivalent kykie in die artikel van die lemma dekko word as behorende tot slengtaal gemerk; die vertaalekwivalent ontrond word gemerk as behorende tot die vaktaal van die fonologie. Die vertaalekwivalent droog word in die artikel van die lemma delactation van die glos van moeder voorsien om die pragmatiese konteks aan te dui waarbinne dit as vertaalekwivalent geld. Die linkerkantste kolom bevat ingevoegde tekste: eerstens, 'n ingevoegde teks wat addisionele semantiese en gebruiksdata oor die lemma deist onder die opskrif "WOORDE IN AKSIE" binne 'n tekskassie bevat (as deel van 'n sekondêre makrostruktuur); tweedens, elemente van 'n verdere sekondêre makrostruktuur waarin vertaalekwivalente soos vergoddelik, vereer en aanbid (wat in die primêre mikrostruktuur as vertaalekwivalente vir die lemma deify aangebied word) asook neerslagtig, bedruk, moedeloos, ensovoorts (wat in die primêre mikrostruktuur as vertaalekwivalente vir die lemma dejected aangebied word) van uitspraakinligting en terugvertalings voorsien word (vgl. Louw en Gouws 1996: 94-96; Gouws 1996: 29-30). Hierdie ingevoegde tekste vorm nie deel van die mikrostruktuur van die woordeboek of onmiddellike stukke van die sentrale lys nie, maar het 'n makrostrukturele optrede as deel van die supplementêre teks (Louw en Gouws 1996: 97). In teenstelling hiermee vorm die sogenaamde "tekskassies" in die Tweetalige Aanleerderswoordeboek/Bilingual Learner's Dictionary (Du Plessis 1993) en Basiswoordeboek van Afrikaans (Gouws et al. 1994) telkens deel van die betrokke artikels en figureer dan as ingevoegde binnetekste (vgl. Gouws 1996: 23-24) — daar is dus nie in hierdie woordeboeke van supplementêre tekste sprake nie; vergelyk die onderstaande uittreksels uit Basiswoordeboek van Afrikaans in (26)(a) en Tweetalige Aanleerderswoordeboek/Bilingual Learner's Dictionary in (26)(b):

(26) (a)

oorhandig (het oorhandig) ww. Wanneer 'n mens iets oorhandig, gee jy dit vir iemand. Die skoolhoof se vrou het die pryse by die prysuitdeling oorhandig. Hierdie dokumente moet persoonlik aan hom oorhandig word. Oorhandig ' $n$ bietjie daardie briefie wat Susan nou net vir (b)

dogter daughter, girl My eldest sister is married and has one daughter/girl and two sons/boys. My oudste suster is getroud en het een dogter en twee seuns.

$\square$ dog ter selfstandige naamwoord (meervoud dogters) 
jou gegee het. Die oorhandiging van die nuwe seiljag aan sy bemanning vind vanaand om agtuur plaas. oorhandiging

Oorhandig is ' $\mathrm{n}$ taamlik formele woord. In die omgangstaal sal 'n mens nooit hoor: Oorhandig daardie appel vir my, want ek is honger, nie, maar wel: Gee vir my die appel aan, want ek is honger.

oorhê (het oor, sal oorhê, het oorgehad, om oor te hê) $w w$. Wanneer 'n mens iets oorhet, hou jy iets oor nadat jy gebruik het wat jy nodig gehad het. Het jy dalk nog geld oor wat jy vir my kan leen, want teen die einde van die maand het ek gewoonlik niks meer oor nie. Sy het nog soveel materiaal oorgehad nadat sy die rok gemaak het dat sy nog 'n bloes ook daaruit kon maak. dogter slaan gewoonlik op iemand se kind en meisie op iemand wat jonger as ' $n$ vrou is, maar die twee woorde is uitruilbaar wanneer jy praat van iemand wat nog op skool of wat kleiner en jonger as 'n meisie is: skooldogter of skoolmeisie, 'n oulike dogtertjie of meisietjie.

dogtertjie ( little girl. They have two children: a boy of eight and a little girl of four. Hulle het twee kinders: 'n seun van agt en 'n dogtertjie van vier. 2 baby girl. My sister had a baby girl last week. My suster het verlede week 'n dogtertjie gekry.

$\square$ dog-ter-tjie selfstandige naamwoord (meervoud dogtertjies)

Op grond van die identifikasie van die tipes kontekstualiserende inskrywings wat in die data (GW, TW, Pharos en RD) voorkom, soos hierbo aangetoon, en die voorafgaande bespreking, kan kontekstualiserende inskrywings soos volg geklassifiseer word:

(27)(a) Diskriminators, waaronder

(i) betekenisverklarings,

(ii) leksikografiese glosse, en

(iii) leksikografiese etikette.

(b) Koteksinskrywings (d.w.s. voorbeeldsinne en -frases), waaronder

(i) kollokasies, en

(ii) vry konstruksies.

(c) Ingevoegde tekste, waaronder

(i) ingevoegde binnetekste (soos "tekskassies" as deel van artikels), en

(ii) ingevoegde buitetekste (soos illustrasieprente, wat buite artikelgrense funksioneer).

Die onderskeid tussen diskriminators, koteksinskrywings en ingevoegde tekste word gemotiveer op grond van leksikografiese funksie, wat die verspreidings- en adresseringstrukture van dié inskrywings bepaal.

\subsection{Verspreidingstruktuur}

Diskriminators tree hoofsaaklik in samehang met lemmata en vertaalekwivalente in die semantiese (sub)kommentaar op. Koteksinskrywings kan binne ' $n$ nie-geïntegreerde mikrostruktuur 'n afsonderlike integraat konstitueer, maar 
tree in elk geval binne die koteksafdeling op, wat nie sonder meer vir diskriminators geld nie. Volgens Gouws (2000a: 4) vind ekwivalentdiskriminasie, en dus kontekstualisering, primêr op artikelinterne vlak plaas. Dit veronderstel dat kontekstualiserende inskrywings hoofsaaklik in die sentrale lys sal voorkom en die kommunikasie-georiënteerde funksies van die woordeboek sal ondersteun (vgl. Gouws en Steyn 2005). Die data toon ook dat kontekstualiserende inskrywings op mikrostrukturele vlak nie onderling eksklusief funksioneer nie, maar dat meer as een tipe met identiese adresse binne 'n enkele woordeboekartikel en selfs binne 'n enkele integraat kan optree (vgl. Beyer 2006a).

Ingevoegde tekste tree óf binne, óf buite die primêre makrostruktuur en óf artikelintern, óf artikelekstern op. Ingevoegde buitetekste moet van buitetekste onderskei word. Terwyl ingevoegde buitetekste in die sentrale lys optree (d.w.s. by die sentrale lys ingevoeg is), tree buitetekste óf voor die sentrale lys as voortekste, óf na die sentrale lys as agtertekste op (vgl. Gouws 2004). Hoewel buitetekste ook die kommunikasie-georiënteerde funksies van die woordeboek kan ondersteun, vervul hulle nie direk en in situ 'n kontekstualiserende funksie nie, hoewel die potensiële rol wat hulle wel in konteksleiding kan speel nie genegeer moet word nie; sodanige rol kan veral deur 'n funksionele mediostruktuur uitgebou word. Vergelyk onder meer Gouws (2004) en Gouws en Steyn (2005) vir besprekings oor buitetekste.

Hoewel geen illustrasieprente in die GW, TW en Pharos voorkom nie, en in die RD tot die agtertekste beperk is, word hulle potensiële optrede in die vorm van ingevoegde tekste as kontekstualiserende inskrywings nie genegeer nie.

Iannucci (1967: 205) stel 'n ekstra-makrotekstuele vorm van kontekstualisering as moontlikheid voor. Dit behels die koördinasie van 'n tweetalige woordeboek met 'n eentalige verklarende woordeboek deur 'n stelsel van nommerverwysings waardeur die semantiese kommentaar in die verklarende woordeboek as kontekstualisering van die ooreenstemmende lemmata en vertaalekwivalente in die tweetalige woordeboek kan dien. Hoewel die implementering van so 'n voorstel nie onmoontlik is nie, erken Iannucci (1967: 205-206) self dat beduidende praktiese probleme met so 'n metode van kontekstualisering kan opduik. Sy voorstel word ook deur Al-Kasimi (1977: 74) as "cumbersome and impractical" gekritiseer, en word hier ook nie verder oorweeg nie.

Soos wat die klassifikasie in (27) suggereer, funksioneer diskriminators en koteksinskrywings op artikelinterne vlak, terwyl ingevoegde binnetekste binne of buite artikelgrense oftewel die mikrostruktuur funksioneer en ingevoegde buitetekste eksklusief daarbuite. Die klas ingevoegde binnetekste kan onderverdeel word in artikelinterne ingevoegde binnetekste en artikeleksterne ingevoegde binnetekste. Eersgenoemde tipe tree binne artikels (as deel van die mikrostruktuur) op, terwyl laasgenoemde tussen artikels optree. Ingevoegde buitetekste tree ook in die sentrale lys (en uitsluitlik artikelekstern) op, maar daar bestaan geen onmiddellik aantoonbare verband tussen sodanige buitetekste en enige woordeboekartikels in die sentrale teks nie, dit wil sê die ingevoegde buitetekste is aan geen spesifieke artikels geadresseer nie. 


\subsection{Adresseringstruktuur}

Die adresseringstrukture wat ten opsigte van kontekstualiserende inskrywings kan geld, is 'n komplekse gegewe wat buite die bestek van hierdie artikel val. Vergelyk Gouws (2000) en Beyer (2006a) vir relevante besprekings.

\section{Slot}

Die wetenskaplike studie van kontekstualisering en konteksleiding in tweetalige woordeboeke behoort te begin met 'n teoretiese fundering van dié verskynsel. Sodanige fundering behoort ' $n$ raamwerk te skep vir sistematiese beskrywing en verdere teorievorming wat hopelik in die praktiese leksikografie in meer gebruikersvriendelike en derhalwe bemagtigende woordeboeke neerslag sal vind. Hierdie artikel is 'n poging om 'n bydrae tot sodanige teoretiese fundering te lewer. Die potensiaal wat 'n kommunikatiewe benadering in 'n gebruikersgerigte metaleksikografie kan inhou, word ook gedemonstreer.

\section{Notas}

1. Die konsepte enkodering en dekodering soos in hierdie artikel toegepas moet nie verwar word met die gebruik van die identiese terme deur o.m. Manley et al. (1988) as sinonieme vir onderskeidelik teksproduksie en teksresepsie in die beskrywing van woordeboekfunksies nie.

2. Kontekstualisering word nie in hierdie bespreking beoordeel nie.

\section{Bronnelys}

\section{Primêre literatuur (woordeboeke)}

Bosman, D.B., I.W. van der Merwe en L.W. Hiemstra. 19848. Tweetalige Woordeboek/Bilingual Dictionary. Kaapstad: Tafelberg.

Du Plessis, M. 1993. Tweetalige aanleerderswoordeboek/Bilingual Learner's Dictionary. Kaapstad: Tafelberg.

Du Plessis, M. (Red.). 2005. Pharos Afrikaans-Engels/Engels-Afrikaans Woordeboek/Dictionary. Kaapstad: Pharos.

Eksteen, L.C. 199714. Groot Woordeboek/Major Dictionary. Kaapstad: Pharos

Gouws, R, I. Feinauer en F. Ponelis. 1994. Basiswoordeboek van Afrikaans. Pretoria: J.L. van Schaik.

Grobbelaar, P. (Red.). 1987. Reader's Digest Afrikaans-Engelse Woordeboek/English-Afrikaans Dictionary. Kaapstad: The Reader's Digest Association of South Africa.

Odendal, F.F. en R.H. Gouws. 20055. Verklarende Handwoordeboek van die Afrikaanse Taal. Kaapstad: Pearson Education South Africa.

Pansegrouw, L.L. 1995. Superblokraaiselwoordeboek. Pretoria: J.L. van Schaik.

Pearsall, J. (Red.). 2001ํ. The Concise Oxford English Dictionary. Oxford: Oxford University Press. 


\section{Sekondêre literatuur}

Al-Kasimi, A.M. 1977. Linguistics and Bilingual Dictionaries. Leiden: E.J. Brill.

Beyer, H.L. 2006. 'n Voorlopige model vir die sistematiese beskrywing van gebruikersvriendelikheid in woordeboeke. Lexikos 16: 46-66.

Beyer, H.L. 2006a. ' $n$ Metaleksikografiese ondersoek na konteksleiding in Afrikaanse vertalende woordeboe$k e$. Ongepubliseerde D.Litt.-proefskrif. Stellenbosch: Universiteit van Stellenbosch.

Crystal, D. 19913. A Dictionary of Linguistics and Phonetics. Oxford: Blackwell.

Gouws, R.H. 1989. Leksikografie. Pretoria/Kaapstad: Academica.

Gouws, R.H. 1996. Bilingual Dictionaries and Communicative Equivalence for a Multilingual Society. Lexikos 6: 14-31.

Gouws, R.H. 1999. Die maatskaplike gerigtheid van die metaleksikografie in 'n meertalige samelewing. Intreerede. Stellenbosch: Universteit van Stellenbosch Drukkery.

Gouws, R.H. 2000. Doeltaalgerigtheid teenoor lemmagerigtheid in vertalende woordeboeke. Tydskrif vir Geesteswetenskappe 40(1): 39-47.

Gouws, R.H. 2000a. Strategies in Equivalent Discrimination. Zettersten, A. and V.H. Pedersen. (Eds.). 2000. Symposium on Lexicography IX. Proceedings of the Ninth International Symposium on Lexicography, April 23-25, 1998 at the University of Copenhagen: 1-23. Tübingen: Max Niemeyer.

Gouws, R.H. 2004. Outer Texts in Bilingual Dictionaries. Lexikos 14: 67-88.

Gouws, R.H. en D.J. Prinsloo. 2005. Principles and Practice of South African Lexicography. Stellenbosch: SUN PreSS.

Gouws, R.H. en M. Steyn. 2005. Integrated Outer Texts: A Transtextual Approach to Lexicographic Functions. Barz, I., H. Bergenholtz en J. Korhonen (Reds.). 2005. Schreiben, Verstehen, Übersetzen und Lernen: Zu ein- und zweisprachigen Wörterbüchern mit Deutsch: 127-136. Frankfurt a.M./Bern/New York/Parys: Peter Lang.

Hausmann, F.J., O. Reichmann, H.E. Wiegand en L. Zgusta. (Reds.). 1989-1991. Wörterbücher. Ein Internationales Handbuch zur Lexikographie/Dictionaries. An International Encyclopedia of Lexicography/Dictionnaires. Encyclopédie internationale de lexicographie. Berlyn/New York: Walter de Gruyter.

Iannucci, J.E. 1967. Meaning Discrimination in Bilingual Dictionaries. Householder, F.W. en S. Saporta (Reds.). 1967. Problems in Lexicography: 201-216. The Hague: Mouton.

Iannucci, J.E. 1985. Sense Discriminations and Translation Complements in Bilingual Dictionaries. Dictionaries 7: 57-65.

Jarošová, A. 2000. Problems of Semantic Subdivisions in Bilingual Dictionary Entries. International Journal of Lexicography 13(1): 11-28.

Kharma, N.N. 1984. Contextualization and the Bilingual Learner's Dictionary. Hartmann, R.R.K. (Red.). 1984. LEXeter '83 Proceedings. Papers from the International Conference on Lexicography in Exeter, 9-12 September 1983: 199-206. Tübingen: Max Niemeyer.

Kromann, H., T. Riiber en P. Rosbach. 1991. Principles of Bilingual Lexicography. Hausmann, F.J. et al. (Reds.). 1989-1991: 2711-2728.

Louw, J.P. 1991. Semantiese norme in die leksikografie. Suid-Afrikaanse Tydskrif vir Taalkunde 9(4): 115-118.

Louw, P.A. en R.H. Gouws. 1996. Lemmatiese en nielemmatiese adressering in Afrikaanse vertalende woordeboeke. Suid-Afrikaanse Tydskrif vir Taalkunde 14(3): 92-100. 
Manley, J., J. Jacobsen en V.H. Pedersen. 1988. Telling Lies Efficiently: Terminology and the Microstructure in the Bilingual Dictionary. Hyldgaard-Jensen, K. en A. Zettersten (Reds.). 1988. Symposium on Lexicography III. Proceedings of the Third International Symposium on Lexicography, May 14-16, 1986, at the University of Copenhagen: 281-302. Tübingen: Max Niemeyer.

Roberts, R.P. 1990. Organization of Information in a Bilingual Dictionary Entry. EURALEX '90 Proceedings. IV International Congress: 219-231. Barcelona: Biblograf.

Svensén, B. 1993. Practical Lexicography. Principles and Methods of Dictionary-Making. Oxford: Oxford University Press.

Tarp, S. 2000. Theoretical Challenges to Practical Specialised Lexicography. Lexikos 10: 189-208.

Van Sterkenburg, P. (Red.). 2003. A Practical Guide to Lexicography. Amsterdam/Philadelphia: John Benjamins.

Wiegand, H.E. 1988. "Shanghai bei Nacht." Auszüge aus einem metalexikographischen Tagebuch zur Arbeit beim Großen Deutsch-Chinesischen Wörterbuch. Germanistische Linguistik 89-90. Wiegand, H.E. (Red.). 1988. Studien zur neuhochdeutschen Lexikographie 6(2): 521-626.

Wiegand, H.E. 1989. Der gegenwärtige Status der Lexikographie. Hausmann, F.J., et al. (Reds.). 1989-1991: 246-280.

Wiegand, H.E. 1990. Printed Dictionaries and their Parts as Texts. An Overview of More Recent Research as an Introduction. Lexicographica 6: 1-126.

Wiegand, H.E. 1996. Das Konzept der semiintegrierten Mikrostrukturen. Ein Beitrag zur Theorie zweisprachiger Printwörterbücher. Wiegand, H.E. (Red.). 1996. Wörterbücher in der Diskussion II. Vorträge aus dem Heidelberger Lexikographischen Kolloquium: 1-81. Tübingen: Max Niemeyer.

Wiegand, H.E. 1997. Die gesellschaftliche Verantwortung der wissenschaftlichen Lexikographie. Hermes 18: 117-202.

Wiegand, H.E. 2002. Equivalence in Bilingual Lexicography: Criticism and Suggestions. Lexikos 12: 239-255.

Zgusta, L. 1971. Manual of Lexicography. The Hague: Mouton.

Zgusta, L. 1987. Translational Equivalence in a Bilingual Dictionary. Dictionaries 9: 1-47. 